\title{
Proteus症候群による椎体と背筋群の過成長に伴う側彎と胸 郭変形のため気管・気管支狭窄をきたした一症例
}

$\begin{array}{llllllr}\text { 佐藤 } & \text { 幸子 } & \text { 乙咩 } & \text { 公通 } & \text { 照屋 } & \text { 愛 } & \text { 山口 } \\ \text { 安保 } & \text { 佳苗 } & \text { 中村 } & \text { 京一 } & \text { 山本 } & \text { 公三 } & \text { 高橋 } \\ \text { 幸雄 }\end{array}$

\begin{abstract}
要約：Proteus症候群は，世界でおよそ100件の報告しかない稀な疾患であり，全身臓器の過 成長をきたす先天性過誤腫を特徵とする。今回，我々は，本症候群による椎体と背筋群の過 成長に伴う側彎と胸郭変形が原因で，進行性の気道狭窄をきたした症例を報告する。症例は 11 歳, 男児。喘息治療で入院中に重度の呼吸困難を呈し, 気管挿管, 人工呼吸管理となった。 胸部 CTにて気管と両側気管支の狭窄を認めた。保存療法では人工呼吸器離脱が困難であった ため, 気管切開後, 胸郭変形に対して胸骨挙上法 (Nuss 法) と胸骨柄切除術を施行した。術後 は人工呼吸器の設定を軽減でき, 人工呼吸補助のままではあるが小児病棟へ退出できた。胸 部 CT所見でも気管・気管支狭窄部の改善を認めた。しかし, その後も胸郭変形が進行し, 約 2ヶ月後に肺炎が契機となって死亡した。胸郭変形への外科的治療により気管・気管支狭窄は 改善したものの，本症例においてはその効果は一過性であった。
\end{abstract}

Key words: (1) Proteus syndrome, (2) thoracic deformity, (3) tracheobronchial stenosis

\section{はじめに}

Proteus症候群は，世界でこれまでにおよそ100件 の報告しかない非常に稀な疾患である。常染色体の異 常とされているが, 原因遺伝子は同定されていない。 身体の一部に過成長を起こすため, 発育過程で変形と 機能障害を起こす。過成長となる部位は様々で, 左右 非対称であることが特徴とされている。手術による治 療が試みられてきたが, 標準的治療法は無く, 十分な 結果が得られない症例も多い。生命予後は良好とされ ているが，過成長を起こす部位によっては生命が妿か されると報告されている1) 3)。

\section{症 例}

症例は 11 歳, 男児。身長 $150 \mathrm{~cm}$, 体重 $70 \mathrm{~kg}$, 体格 指数 (body mass index, BMI) 31.1。

8歳時にProteus症候群と診断された。生後 8 カ月 時に足底部腫瘤に対する手術(詳細不明), 1 歳6力月 時に脂肪腫切除術, 9歳時にアキレス腱延長術と内反 足に対する脛骨骨切り術の手術歴があった。8歳時か
ら歩行困難が出現し, 脊髄係留症候群を指摘されてい たが経過観察されていた。また, 5 歳時から小児喘息 を指摘されており，10歳時に喘息発作での入院歴が あった。この時, 精査にて気管・気管支の狭小化を指 摘されていたが, 喘息症状との関連は指摘されていな かった。

11歳3 月月時に, Proteus症候群が原因と考えられ る腰椎症に対して, 当院脊椎外科にて全身麻酔下に腰 椎椎弓切除術を施行した。全身麻酔導入後に気管挿管 して腹臥位にした際に，喘鳴出現と気道内圧の上昇を 認めた。麻酔覚醒時に, 抜管は可能であったが喘鳴が 残存し，喘息発作と判断された。この際にも，喘息症 状に対して気管・気管支狭窄の影響が疑われたが主な 原因とは考えられていなかった。術後に小児科転科と なり, 約 2 力月間入院していた。外泊訓練として修学 旅行に参加したが, 㷌院後から咽頭痛を認め, ウイル ス性上気道炎として加療されていた。前日から喘鳴が 出現し， $\beta$ 刺激薬吸入, デキサメタゾン内服を開始し ていたが, 突然呼吸困難が増悪し痤卛を伴った。ヒド ロコルチゾン静注, エピネフリン皮下注を行い, マス 
(a)

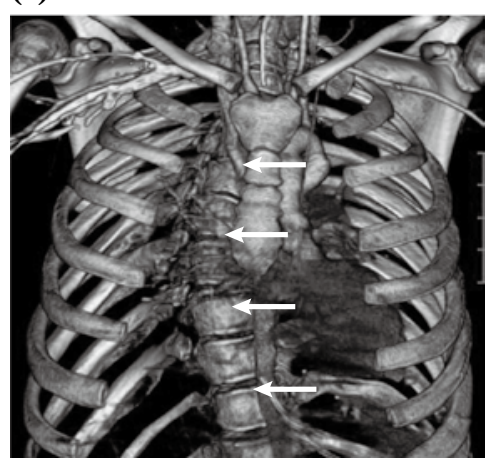

(b)

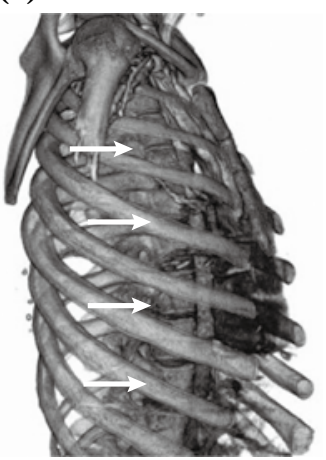

Fig. 1 The 3-dimensional(3D)reconstructed $\mathrm{CT}$ on admission to the ICU showed thoracic skeleton and heart and vessels

(a) The arrows indicate scoliosis, the thoracic vertebrae deviate to the right.

(b) The arrows indicate the prominent protrusion of thoracic vertebrae.
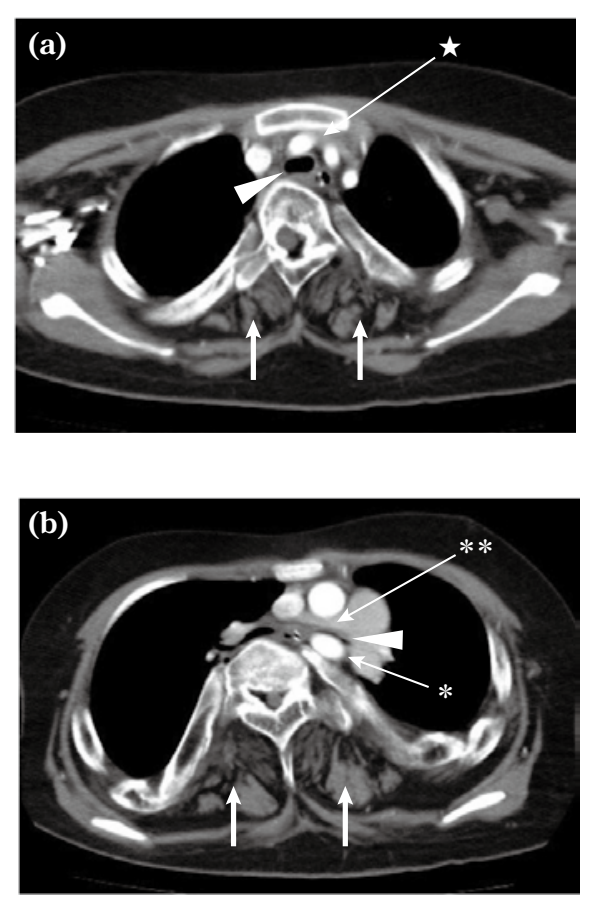

(c)
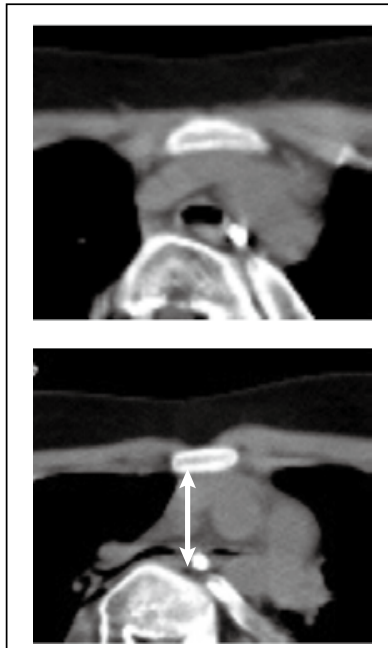

Day 1

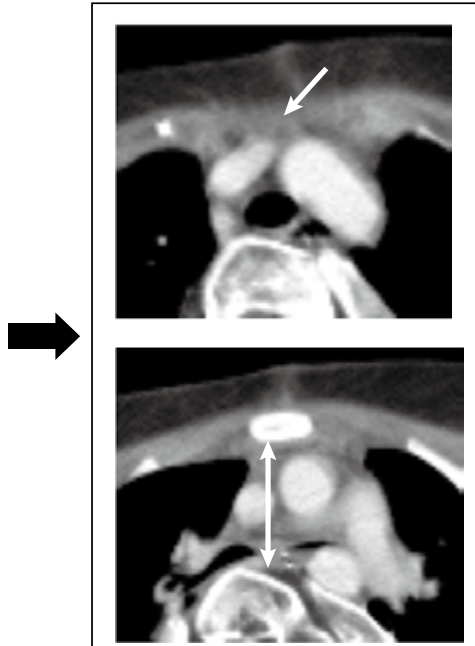

Day 44

Postoperative evaluation

Fig. 2 (a), (b) Chest CT on admission to the ICU showed the vertebrae to be pushed anteriorly and turned to the right, and revealed thoracic deformity. The arrows indicate the overgrown back muscles (a) The arrowhead indicates the compressed trachea, sandwiched between the vertebra and brachiocephalic trunk.

$\star$ Brachiocephalic trunk.

(b) The arrowhead indicates severe stenosis of the left bronchus.

* Thoracic aorta, ** right pulmonary artery.

(c) Comparison of chest CT between preoperative (day 1) and postoperative (day 44)

The distance from the sternum to the vertebra increased by approximately $10 \mathrm{~mm}$ after surgery. The white arrow indicates the episternum was resected.

クによる補助換気を行ったが酸素化が改善せず, 気管 挿管の後, ICU入室となった。

ICU入室時の意識レベルはGlasgow coma scale E1VtM4, バイタルサインは血圧 160/80 mmHg, 心拍 数 $160 / \mathrm{min}$, 体温 $39.5^{\circ} \mathrm{C}$ であった。身体所見では, 胸 郭の変形を認め, 呼吸音は左肺で減弱しており, 肺全 体にrhonchiとwheezeを聴取した。心音には異常は なかった。両下腿にはProteus症候群の特徴とされる 裂足と変形を認めた。血液検查では, 白血球は 31,700
$/ \mu l$ と増加して扔り, 好中球の左方移動を認め, CRP は $3.52 \mathrm{mg} / \mathrm{d} l$ と陽性であった。動脈血液ガス分析で は $\mathrm{PaCO}_{2} 157 \mathrm{mmHg}, \mathrm{BE}-8.8 \mathrm{mmol} /$ と混合性アシ ドーシスを認めたが, $\mathrm{P} / \mathrm{F}$ 比 336 と低酸素血症は軽度 であった。

ICU入室時の胸部 X線写真では胸椎の側彎, 心胸比 の拡大, 左肺野全体の透過性低下を認めた。胸部 C T の3D構築画像では胸椎の側彎と前方への偏位を認め た (Fig. 1)。胸部CTでは椎体と椎体周囲の背筋群の 
過成長, 側彎, 胸郭の変形を認めた（Fig. 2)。その結果, 心臓が左胸郭内に偏位して前後から圧迫されており, 気管と両側気管支が椎体と胸骨に挟まれて狭小化して いた。

気道感染症によって喘息重積発作が惹起された可能 性と, 機械的な気道狭窄が存在していたことが急激な 呼吸不全の原因と考元, 抗菌薬, 気管支拡張薬による 加療を開始した。気道抵抗が高く pressure control (PC) ventilationのPC $32 \mathrm{cmH}_{2} \mathrm{O}$ にて換気量は 250 $\mathrm{m} l$ しか得られず, 揮発性麻酔薬 (セボフルラン) の吸 入も施行した。胸部CTではごくわずかな領域の浸潤 影のほかに明らかな肺炎像は指摘できなかったが, 気 管チューブからは黄色粘調痰が吸引され, 痰培養で Haemophilus influenzaeが分離された。意識レベルは 早期に正常に回復した。

抗菌薬 (セフォタキシム) 投与, 気管支拡張薬吸入に よる加療を継続して, 呼吸器感染症状と全身状態の改 善を得たが, 人工呼吸器のウィーニングは困難であっ た。身体所見において呼吸音の改善は認めたものの, rhonchi と wheezeが残存し, 特に左肺の呼吸音は減弱 していた。長期人工呼吸補助が必要となるため, 入室 17 日目に気管切開を施行した。その後も人工呼吸器 設定は pressure support (PS) ventilationにてPS 20 $\mathrm{cm} \mathrm{H}_{2} \mathrm{O}$ 程度の補助が必要であり, 気管・気管支の機 械的狭窄が原因と考えられた。約半年前の胸部 C T と 比較しても胸郭変形は進行しており, 原疾患が急速に 進行したと考えられた。

本症候群に対する標準的な治療法は無いため, 外科 的治療法または気管ステントによる治療を検討した。 呼吸状態が不安定であることを考慮して，比較的侵襲 が低いNuss 法による胸郭挙上法と胸骨柄切除による 手術療法を選択した。入室 21 日目に人工呼吸器を装 着したままで,一旦ICUを退室した。

第34病日に, Nuss 法, 胸骨柄切除術, 第 3,4 肋骨切 離術を施行し, 術後管理目的で再びICU入室となっ た。術後経過はおお抒むね順調で, 人工呼吸補助をPS $10 \mathrm{cmH}_{2} \mathrm{O}$, PEEP $5 \mathrm{cmH}_{2} \mathrm{O}$ まで軽減でき, 第 50 病日 にICU退室となった。第44病日（術後10日目）に施行 した胸部CTにおいて, 胸骨後面から椎体前面までの 距離が術前は50 mmであったものが $60 \mathrm{~mm}$ まで拡大 しており, 左肺の含気の改善も認められた (Fig. 2c)。 病棟では人工呼吸補助を少しずつ減らし，一時的には 車椅子に移乗することもできるようになった。しかし， 再び人工呼吸補助が減らせなくなり，第 109 病日に肺 炎が原因で呼吸状態が悪化して死亡した。同日に施行 した胸部CTでは, 過成長が進行したために胸郭変形
が増し, 再び縦隔の前後径が短縮していることが確認 された。

\section{考 察}

Proteus症候群において側彎を認めることが多いこ とは報告されているが2),4),5), 進行性の気管・気管支狭 窄を呈した報告は無い。本症例では側彎, 胸郭変形の 結果, 縦隔の前後径が短縮し, 心臓, 大血管, 気管, 肺 などが変形をきたし, 気管・気管支狭寉という生命に かかわる病態を引き起こした。主な狭窄部位は腕頭動 脈レベルと大動脈と肺動脈に挟まれたレべルの2か所 であった。

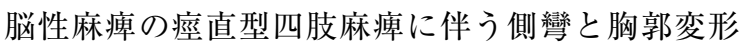
で, 同様の治療困難な気管狭窄をきたし, 不幸な転帰 をとったという報告がある6)。また，側彎を呈する他 の疾患でも, 大血管に圧迫されて, 主に左気管支の狭 窄が起こると報告されている7)。一方でNuss法によ る胸郭挙上法が著効した症例報告もある ${ }^{8)}$ 。

本症例において確立された治療法はないが, (1)胸郭 を前方に拡張する手術療法, (2)背側からの脊椎と背筋 に対する手術療法, (3)気管ステント留置の3法が考元 られた。本症例は成長期の小児であり今後も組織の過 成長が進行する9)と予測して, まずは胸骨挙上法 (Nuss 法)に胸骨柄切除を追加した外科治療を選択し た。Nuss法は, 漏斗胸の手術として標準的に行われ ている術式である。ペクタスバーという金属の棒を形 成し, 前胸部胁骨に沿わせて胸骨の毫側に挿入して肋 骨に固定することで, 胸骨挙上と胸郭拡大を得る方法 である。その結果, 気管・気管支の狭窄が緩和されれ ば伏臥位をとることが可能となり, 背側からの椎体へ の手術療法が可能となることも視野に入れた選択で あった。

脊椎に対する背側からの手術療法は以下の 3 つの理 由で選択しなかった。(1)全身麻酔下に伏卧位をとるこ とで換気困難となる可能性が高いこと, (2)背筋が過成 長しているため手術手技が困難であり, 出血が多量と なる可能性があり, 長時間の大侵襲手術となること, (3)過成長部に手術侵襲を加えた後の組織反応は予測不 能10)であること。

気管ステントは以下の5つの理由で選択しなかっ た。(1)小児に対する気管ステントの有効性は確立され ていないこと, (2)本症例は成長期の児であり今後も気 管径が変化すること, (3)進行性の過成長によって壁外 性圧迫が進行した場合にステントによる内腔確保は困 難となること, (4)周囲の大血管と瘦孔を形成する可能 性があること, (5)左気管支全長の内径が $2 \mathrm{~mm}$ と非常 
に細く手技が困難であること11)。

喘鳴を伴う呼吸困難を呈し喘息発作と診断された症 例の中に, 中枢気道の狭窄が主病態である場合があり 注意が必要といわれている。本症例も以前から喘息と 診断されており, その呼吸器症状の一因として中枢気 道狭窄が関係していた可能性は考えられる。気管・気 管支狭窄に対する治療法をより早期から検討すること で，安全に伏臥位をとれるため，椎体や背筋に対する 背側からの手術療法も選択し得たかもしれない。 Proteus症候群による過成長は進行性でコントロール が困難とされており, 本症例では重要臓器に及ぼす影 響が大きかったため, 生命予後を悪くする結果となっ た。胸郭前方への圧迫解除によって気管・気管支狭窄 部の拡張が得られたが, 本症例においては胸郭変形の 進行が速かったためその効果は一過性であった。

\section{結 語}

Proteus 症候群による椎体と背筋群の過成長に伴う 側彎と胸郭変形が原因となって, 重度の気管・気管支 狭窄が引き起こされた症例を経験した。胸郭前方への 圧迫解除を行う手術療法によって気管・気管支狭窄部 の拡張が得られたが, 胸郭変形が進行したため効果は 一過性であった。

本稿の内容は, 第 37 回日本集中治療医学会学術集会 $(2010$ 年, 広島)にて報告した。
本稿のすべての著者には規定されたCOIはない。

\section{文 献}

1) Biesecker L. The challenges of Proteus syndrome: diagnosis and management. Eur J Hum Genet 2006;14: 1151-7.

2) Cohen MM Jr. Proteus syndrome: An update. Am J Med Genet C Semin Med Genet 2005;137:38-52.

3) Biesecker LG, Happle R, Mulliken JB, et al. Proteus syndrome: Diagnostic criteria, differential diagnosis, and patient evaluation. Am J Med Genet 1999;84:389-95.

4) Turner JT, Cohen MM Jr, Biesecker LG. Reassessment of the Proteus syndrome literature: application of diagnostic criteria to published cases. Am J Med Genet 2004;130A:111-22

5) Famis-Dow CA, Turner J, Biesecker LG, et al. Radiologic manifestations of Proteus syndrome. Radiographics 2004; 24:1051-68.

6) 田中正樹, 渡辺裕貴, 福島克之, 他. 脊柱と胸骨の圧迫に よる致死的な気管狭窄を合併した㽷直型四肢麻痺の 3 症 例。脳と発達 2001:33:347-50。

7) Donnelly LF, Bisset GS 3rd. Airway compression in children with abnormal thoracic configuration. Radiology 1998;206:323-6.

8) 菅野幹雄, 江川善康, 川人智久, 他. 胸郭変形に伴う気道 閉塞に対してNuss 法を用いた胸郭挙上術が有効であった 1 例. 日小外会誌 2006;42:574-8.

9) 久保田健夫, 福嶋義光. Proteus症候群. 早藤 弘. 別冊 日本臨床 領域別症候群シリーズNo.30神経症候群 V. 大 阪：日本臨床社；2000.p. 66-7.

10) 城 良二. Proteus症候群. 小児内科 1998;30:349-51.

11) Nicolai T. Airway stents in children. Pediatr Pulmonol 2008;43:330-44 


\section{Abstract}

Tracheobronchial stenosis due to thoracic deformity and scoliosis which were caused by progressive overgrowth of vertebrae and back muscles with Proteus syndrome: a case report

Sachiko Sato, Kimimichi Otome, Ai Teruya, Satoshi Yamaguchi, Kanae Abo, Kyoichi Nakamura, Kozo Yamamoto, Yukio Takahashi

Department of Anesthesiology, Intensive Care, Kameda Medical Center

929 Higashicho, Kamogawa, Chiba 296-8602, Japan

Proteus syndrome is a rare disorder of patchy or mosaic postnatal overgrowth, with only about 100 cases having been reported to date. We describe a case of progressive tracheobronchial stenosis induced by thoracic deformity and scoliosis which were caused by progressive overgrowth of vertebrae and back muscles with Proteus syndrome. An 11-year-old boy suddenly developed severe dyspnea during hospitalization for treatment for asthma, then he was intubated and on mechanical ventilation. Chest CT revealed severe stenosis of trachea and bilateral bronchi. Despite medical treatment he could not be weaned from ventilator. He underwent tracheotomy and additional intervention to the thoracic deformity, the Nuss procedure, to push the sternum ante-ward with a curved steel bar, and episternectomy. Although he could not be taken off the ventilator postoperatively, reduced support was feasible and he was transferred to the pediatric ward. Chest CT showed amelioration of the tracheobronchial compression. Approximately 2 months later, however, the thoracic deformity worsened and the bronchi became stenotic again. He ultimately died of pneumonia. Although tracheobronchial stenosis was improved by the surgical intervention, its effect did not last long.

Key words: (1) Proteus syndrome, (2) thoracic deformity, (3) tracheobronchial stenosis

J Jpn Soc Intensive Care Med 2012;19:650-4. 